\title{
Single Adsorption of Diclofenac and Ronidazole from Aqueous Solution on Commercial Activated Carbons: Effect of Chemical and Textural Properties
}

\section{Adriana I. Moral-Rodríguez}

Universidad Autonoma de San Luis Potosi Facultad de Ciencias Quimicas

Roberto Leyva-Ramos ( $\nabla$ rir@uasip.mx )

Universidad Autonoma de San Luis Potosi, Facultad de Ciencias Quimicas, Centro de Investigación y

Estudios de Posgrado https://orcid.org/0000-0003-2970-6149

\section{Esmeralda Mendoza-Mendoza}

Universidad Autonoma de San Luis Potosi, Facultad de Ciencias Quimicas, Centro de Investigación y

Estudios de Posgrado

\section{Paola Elizabeth Díaz-Flores}

Autonomous University of San Luis Potosi Faculty of Agriculture and Veterinary: Universidad Autonoma de San Luis Potosi Facultad de Agronomia y Veterinaria

\section{Damarys H. Carrales-Alvarado}

Institute of Catalysis and Petrochemistry: Instituto de Catalisis y Petroleoquimica

\section{María F. Alexandre-Franco}

Universidad de Extremadura, Facultad de Ciencias - Centro Universitario de Merida

\section{Carmen Fernández-González}

Universidad de Extremadura, Facultad de Ciencias da Coruña Facultade de Dereito: Universidade da Coruna Facultade de Dereito

\section{Research Article}

Keywords: Activated carbon, adsorption mechanism, diclofenac, ronidazole, surface chemistry.

Posted Date: July 6th, 2021

DOl: https://doi.org/10.21203/rs.3.rs-614796/v1

License: (c) (1) This work is licensed under a Creative Commons Attribution 4.0 International License. Read Full License

Version of Record: A version of this preprint was published at Environmental Science and Pollution Research on January 11th, 2022. See the published version at https://doi.org/10.1007/s11356-021- 
17466-7.

Page 2/24 


\section{Abstract}

The importance of the textural and physicochemical characteristics upon the adsorption capacity of the commercial activated carbons (ACs) Coconut, Wood, Merck, Darco and Norit towards ronidazole (RNZ) and diclofenac (DCF) from water solution was investigated thoroughly in this work. At $\mathrm{pH}=7$, Coconut $\mathrm{AC}$ and Wood AC presented the highest adsorption capacity towards RNZ (444 mg/g) and DCF $(405 \mathrm{mg} / \mathrm{g})$, correspondingly. The maximum mass of RNZ adsorbed onto Coconut AC was higher in this study than those outlined previously in other works. Besides, the maximum capacity of Wood AC for adsorbing DCF was comparable to those found for other ACs. The findings disclosed that the adsorption capacity of all the ACs was remarkably increased by surface area and was favored by incrementing the acidic site concentration. The $\pi-\pi$ stacking interactions were the predominant adsorption mechanism for the RNZ and DCF adsorption on ACs, and the acidic sites favored the adsorption capacity by activating the $\pi-\pi$ stacking. Electrostatic interactions did not influence the adsorption of RNZ on Coconut AC, but electrostatic repulsion decreased that of DCF on Wood AC. In the range of $15-25^{\circ} \mathrm{C}$, the adsorption of RNZ and DCF on the Coconut and Wood ACs was endothermic, but the capacity remained essentially constant by elevating the temperature from 25 to $35^{\circ} \mathrm{C}$.

\section{Introduction}

The excessive utilization of pharmaceuticals in animal and human health care has originated that considerable amounts of drugs are being discharged to the aquatic environment (surface, drinking and ground waters), sediments, soil, and food chains (Wang and Wang 2016). Effluents from municipal wastewater treatment plants release pharmaceutical compounds into surface water sources since the existing biological water treatment processes do not successfully remove these compounds. Antibiotics and anti-inflammatories are some of the most commonly detected organic microcontaminants in municipal wastewater, posing a disturbing hazard since these compounds are toxic even at trace levels (Jeon and Hollender 2019). The scarce information about the toxicity of these compounds constitutes a potential hazard to human health (Halling-Sørensen et al. 1998; Ternes and Hirsch 2000).

Antibiotics are broadly prescribed to prevent or treat microbial infections, and several of them are recalcitrant or difficult to decompose in aerobic biological treatment processes (Kümmerer 2009). Distinct antibiotics were found in the hospital residual waters, industrial and municipal wastewater and surface water. Amoxicillin (900-9940 ng/L) (Watkinson et al. 2009), ampicillin (5800 ng/L) (Lin et al. 2008), cephalexin (3100-64000 ng/L) (Watkinson et al. 2009), ciprofloxacin (11-15000 ng/L) (Spongberg and Witter 2008; Watkinson et al. 2009), sulfamethoxazole (4-9460 ng/L) (Díaz-Cruz et al. 2008) and tetracycline (15000 ng/L) (Lin et al. 2008) are some of the antibiotics detected in water resources.

Notwithstanding, the nonsteroidal anti-inflammatory pharmaceuticals (NSAIDs) are being widely prescribed for curing dysmenorrhea fever, headaches, inflammatory arthropathy, osteoarthritis and rheumatoid arthritis, among others (Richard et al. 2007). These anti-inflammatories have been found not only in surface waters but also in residual waters. Several studies have documented the harmful effects 
of NSAIDs upon animals, human beings and water organisms (Du et al. 2016). Among the NSAIDs frequently detected in water are acetaminophen (211 ng/L) (Santos et al. 2013), diclofenac (60-1900 ng/L) (Gómez et al. 2007), famotidine (94 ng/L) (Lin et al. 2008) and ibuprofen (300 ng/L) (Lin and Tsai 2009).

Various processes have been applied to eliminating pharmaceutical compounds in water. Among these, advanced oxidation processes, adsorption, photodegradation, soil sorption, electrochemical degradation and biosorption by aquatic plants are being successfully applied lately (Chianese et al. 2016; MoralRodriguez et al. 2016; Martínez-Costa et al. 2020).

Adsorption is a separation process that has attracted considerable attention due to the low operating costs and availability of different adsorbents. Different activated carbons (ACs) have been prepared for removing various drugs from water solutions. Malhotra et al. (Malhotra et al. 2018) examined the adsorption of diclofenac (DCF) on an AC synthesized by chemical activation of tea residues using $\mathrm{ZnCl}_{2}$, $\mathrm{K}_{2} \mathrm{CO}_{3}, \mathrm{KOH}$ and $\mathrm{H}_{2} \mathrm{SO}_{4}$, denoted as $\mathrm{AC} 1, \mathrm{AC2}, \mathrm{AC} 3$ and $\mathrm{AC4}$, correspondingly. The results showed that $\mathrm{AC} 1$ at a pH of 6.47 presented the highest adsorption capacity $(61 \mathrm{mg} / \mathrm{g})$ than the other ACs. Moreover, it was reported that the textural properties of the ACs depend on the activating agent used. The adsorption capacity decreased in the following order: AC1 > AC2 > AC3 > AC4; likewise, the surface diminished in the same order.

Recently, the adsorption capacity of a commercial AC towards DCF was enhanced by modifying the commercial $\mathrm{AC}$ using chemical activation with $\mathrm{CO}_{2}$, and the adsorption capacity was raised nearly linearly with the AC surface area (Moral-Rodríguez et al. 2019). In another work, ACs were synthesized from sewage sludge that was mixed with a $\mathrm{ZnCl}_{2}$ solution, using different ratios of $\mathrm{ZnCl}_{2} /$ sludge $(0.5,1.0$, and 1.5) and carbonized at different temperatures $\left(500,650\right.$ and $800^{\circ} \mathrm{C}$ ) (dos Reis et al. 2016). These ACs were applied to remove nimesulide (NM) and DCF in a water solution, and the maximum mass of NM and DCF adsorbed was 66.4 and $157.4 \mathrm{mg} / \mathrm{g}$, correspondingly.

Moral-Rodríguez et al. (2016) researched for eliminating ronidazole (RNZ) and sulfamethoxazole (SMX) from a water solution bt adsorption on a commercial AC, designated as F400. The findings disclosed that the adsorption of SMX on F400 relied on the temperature, ionic strength, $\mathrm{pH}$ and aqueous matrix, whereas the operating conditions did not change the adsorption of RNZ on F400. Furthermore, the uptake of RNZ adsorbed on F400 was higher (352.26-518.39 mg/g) than that of SMX (126.64-445.77 mg/g). It was also demonstrated that the F400 capacity towards RNZ and SMX was significantly dependent upon its textural properties and the molecular size of each antibiotic.

Although the effectiveness of adsorption on carbonaceous materials for eliminating pharmaceutical compounds in aqueous solution has been extensively analyzed, the influence of their chemical and textural properties on their adsorption capacity has to be studied thoroughly. Therefore, this study's principal goal was to analyze the adsorption equilibrium of DCF and RNZ on five commercial ACs having different physicochemical characteristics. Besides, the dependence of the adsorption capacities of these 
ACs regarding $\mathrm{pH}$, ionic strength and solution temperature was investigated in detail. Moreover, the adsorption mechanisms of RNZ and DCF on the ACs were explained.

\section{Experimental Methodology}

\subsection{Adsorbents and characterization}

Five commercial ACs were used and were designated as Coconut, Wood, Merck, Darco and Norit. The ACs were pretreated by washing with water, drying in an electric oven overnight $\left(T=120^{\circ} \mathrm{C}\right)$, sieving and storing in a sealed vessel. The particles of ACs have a mean diameter of $0.056 \mathrm{~mm}$.

The textural properties of $A C s$, namely surface area $\left(S_{B E T}\right)$, pore volume $\left(V_{P}\right)$, and average pore diameter $\left(d_{p}\right)$, were assessed from the adsorption-desorption isotherm of $N_{2}$, which was measured in a physisorption apparatus, Micromeritics, ASAP 2020. The determination of $S_{B E T}$ was carried out by the method proposed by Brunauer, Emmett, and Teller (BET) (Brunauer et al. 1938). The DubininRadushkevich (DR) isotherm (Rouquerol et al. 2014) was applied to evaluate the micropore volume $\left(\mathrm{V}_{\text {mic }}\right)$, specific micropore area $\left(S_{\text {mic }}\right)$ and average micropore width $\left(L_{0}\right)$. Lastly, the pore size distribution of each $A C$ was computed using the density functional theory. The basic and acidic sites concentrations on the AC surface were ascertained by Boehm's titration method (Boehm 1966); otherwise, the surface charge of the adsorbents was assessed by the acid-base titration technique developed by Babic et al. (1999).

\subsection{Pharmaceuticals compounds}

The pharmaceutical compounds employed in this study were ronidazole (RNZ) and diclofenac sodium (DCF), supplied by Merck. Table 1 displays the chemical characteristics and molecular structure of RNZ and DCF. The molecular model of each compounds was obtained by applying the hybrid density functional b3lyp. Figure $1 \mathrm{a}$ and $1 \mathrm{~b}$ show the speciation diagrams for RNZ and DCF in water solutions, calculated using the corresponding dissociation constants (see Table 1). 
Table 1

Molecular structure and physicochemical properties of RNZ and DCF.

\begin{tabular}{|c|c|c|c|c|c|}
\hline Compound & Molecular structure & $\begin{array}{l}\text { Molecular } \\
\text { Weight } \\
(\mathrm{g} / \mathrm{mol})\end{array}$ & $\begin{array}{l}\text { Dimensions } \\
X, Y, Z \\
(n m)\end{array}$ & $\mathrm{pK}_{\mathrm{ow}}$ & $\mathrm{pK}_{\mathrm{a}}$ \\
\hline $\begin{array}{l}\text { Ronidazole } \\
\mathrm{C}_{6} \mathrm{H}_{8} \mathrm{~N}_{4} \mathrm{O}_{4} \\
\text { (RNZ) }\end{array}$ & & 200.15 & $\begin{array}{l}X: 0.913 \\
Y: 0.448 \\
Z: 0.264\end{array}$ & 0.38 & $\begin{array}{l}\mathrm{pKa}_{1}: 1.32 \\
\mathrm{pKa}_{2}: 12.99\end{array}$ \\
\hline $\begin{array}{l}\text { Diclofenac sodium } \\
\mathrm{C}_{14} \mathrm{H}_{10} \mathrm{Cl}_{2} \mathrm{NNaO}_{2} \\
\text { (DCF) }\end{array}$ & & 318.13 & $\begin{array}{l}X: 0.960 \\
Y: 0.708 \\
Z: 0.472\end{array}$ & 3.91 & pKa: 4.0 \\
\hline
\end{tabular}

The determination of RNZ and DCF was performed by UV-Visible spectrophotometry. The calibration curves for RNZ and DCF were prepared from standard solutions having concentrations from 100 to 1000 $\mathrm{mg} / \mathrm{L}$. A spectrophotometer, Shimadzu (model UV 2600), was employed to determine the absorbances of RNZ and DCF solutions at wavelengths of 309 and $276 \mathrm{~nm}$, correspondingly, and the calibration curves were made at the particular $\mathrm{pH}$ of the RNZ and DCF sample solutions.

\subsection{Technique for procuring the adsorption data of RNZ and DCF}

A solution with an ionic strength $(0.01 \mathrm{~N})$ and a specific $\mathrm{pH}$ was fixed by combining appropriate volumes of $0.01 \mathrm{~N} \mathrm{HCl}$ and $\mathrm{NaOH}$ solutions. This constant ionic strength solution was employed for fixing all RNZ and DCF solutions, having initial concentrations varying from 100 to $1000 \mathrm{mg} / \mathrm{L}$.

The data for the RNZ and DCF adsorption on the ACs were obtained in an experimental adsorber operated in batch mode. An AC mass of $50 \mathrm{mg}$ and $40 \mathrm{~mL}$ of the RNZ or DCF solutions of different initial concentrations were added into $50 \mathrm{~mL}$ Falcon tubes (adsorber). Afterward, the Falcon tube was set down in a thermostatic bath, allowing the solution and ACs to reach adsorption equilibrium. In preliminary tests, the concentration of the pharmaceuticals in solution was monitored daily, and the concentration did not change after 5 days so that 7 days was sufficient time to approach equilibrium. Three times daily, the adsorber solutions were mechanically shaken for 15 min by placing the adsorbers on top of an Orbital 
Shaker TS-100. Posterior to 7 days, a solution was taken out and analyzed by the analytical method detailed above to quantify the equilibrium concentration of the pharmaceutical.

At $\mathrm{T}=25^{\circ} \mathrm{C}$, the dependence of the adsorption equilibrium on $\mathrm{pH}$ was analyzed by procuring the adsorption data at $\mathrm{pH}$ of 3,7 and 11 for RNZ and pH of $6,7,9$ and 11 for DCF. In all the experimental runs, few drops of $\mathrm{HCl}$ and $\mathrm{NaOH}$ solutions of $0.01 \mathrm{~N}$ were supplemented to keep the solution $\mathrm{pH}$ constant. Moreover, the temperature influence was analyzed by measuring the adsorption equilibrium data at 35,25 , and $15^{\circ} \mathrm{C}$ and $\mathrm{pH}=7$. The mass adsorbed of RNZ and DCF on the carbons was appraised by conducting a mass balance of the pharmaceutical in the batch adsorber, expressed as follows:

$$
q=\frac{V\left(C_{0}-C_{e}\right)}{m}
$$

Where q denotes the mass of RNZ or DCF adsorbed at equilibrium $(\mathrm{mg} / \mathrm{g}), \mathrm{V}$ represents the volume of the RNZ or DCF solutions $(L), C_{0}$ is the initial concentration of the RNZ or DCF $(\mathrm{mg} / \mathrm{L}), \mathrm{C}_{\mathrm{e}}$ is the equilibrium concentration of RNZ or DCF ( $\mathrm{mg} / \mathrm{L})$, and $\mathrm{m}$ is AC mass $(\mathrm{g})$.

\section{Results And Discussion}

\subsection{Properties of Commercial ACs}

The textural characteristics $S_{B E T}, V_{P}, d_{P}, V_{\text {mic }} L_{0}$, and $S_{\text {mic }}$ of all $A C s$ are registered in Table 2. The $S_{B E T}$ of the ACs decreased from 1357 to $510 \mathrm{~m}^{2} / \mathrm{g}$, and the decreasing order is as follows: Wood > Merck > Coconut $>$ Norit $>$ Darco. Furthermore, the total $V_{p}$ was evaluated at $\left(P / P_{s}\right)=0.99$ and varied from 0.44 to $1.18 \mathrm{~cm}^{3} / \mathrm{g}$, showing that the porosity of the ACs changed broadly. 
Table 2

Textural properties of the commercial ACs.

\begin{tabular}{|c|c|c|c|c|c|c|}
\hline AC & $\begin{array}{l}S_{B E T} \\
\left(m^{2} / g\right)\end{array}$ & $\begin{array}{l}V_{P}^{a} \\
\left(\mathrm{~cm}^{3} / \mathrm{g}\right)\end{array}$ & $\begin{array}{l}d_{p^{b}} \\
(n m)\end{array}$ & $\begin{array}{l}V_{\text {mic }}{ }^{c} \\
\left(\mathrm{~cm}^{3} / \mathrm{g}\right)\end{array}$ & $\begin{array}{l}L_{0}^{d} \\
(n m)\end{array}$ & $\begin{array}{l}S_{\text {mic }} \\
\left(\mathrm{m}^{2} / \mathrm{g}\right)\end{array}$ \\
\hline Wood & 1357 & 1.18 & 3.51 & 0.40 & 1.41 & 746 \\
\hline Merck & 1074 & 0.57 & 2.13 & 0.33 & 1.27 & 554 \\
\hline Coconut & 960 & 0.44 & 1.81 & 0.38 & 0.97 & 800 \\
\hline Norit & 646 & 0.55 & 3.43 & 0.28 & 0.93 & 433 \\
\hline Darco & 510 & 0.58 & 5.34 & 0.21 & 1.22 & 328 \\
\hline \multicolumn{7}{|c|}{ a Total pore volumen } \\
\hline \multicolumn{7}{|c|}{ b Average pore diameter } \\
\hline \multicolumn{7}{|c|}{${ }^{c}$ Micropore volume } \\
\hline
\end{tabular}

The adsorption isotherms of $\mathrm{N}_{2}$ on the ACs are plotted in Fig. S.1. According to the classification recommended by IUPAC (Rouquerol et al. 2014), the isotherm shapes of Coconut and Merck ACs are type la (Fig. S.1 a) and Ib (Fig. S.1 b), respectively. These isotherms are reversible and have a high opening in the adsorption shoulder, which is characteristic of microporous materials. For the isotherm la, the type of microporosity is narrower if compared to that of isotherm lb, where the diameters of the micropores are wider according to the opening of the adsorption shoulder (see isotherm Ib). The adsorption isotherms of the Darco, Norit, and Wood ACs have shapes of type Ilb (Fig. S.1 c, d, and e), distinctive of mesoporous materials, showing the hysteresis loops $\mathrm{H}_{3}$ and $\mathrm{H}_{4}$ type. The hysteresis loop $\mathrm{H}_{3}$ (Fig. S.1 c) often occurs in materials formed by aggregates of particles with sheet morphology, while the $\mathrm{H}_{4}$ (Fig. S.1 d and e) is typical of activated carbons and other adsorbents, which have slit shape pores and high distribution of micropores (Boehm 1966).

The $\mathrm{V}_{\text {mic }}$ of the Coconut, Merck, Norit, Darco and Wood ACs represented 86, 58, 51, 36 and $34 \%$ of the total $V_{p}$, respectively, confirming that the Coconut and Merck ACs consisted mainly of micropores.

Figure S.2 displays the cumulative pore volume and distribution of pore size for all ACs. The accumulated pore volume distribution of the Coconut AC (see Figure S.2 a) shows that the volume of micropores is $94.3 \%$ of the entire pore volume, although the remaining $5.7 \%$ is mesoporous. Furthermore, the pore size distribution is almost unimodal, and the approximate pore diameter was about $0.65 \mathrm{~nm}$. Likewise, in Figure S.2 e, the cumulative volume distribution of the Wood AC revealed that the micropores and mesopores represented 49 and $51 \%$ of the total pore volume, correspondingly. On the other hand, it can 
be corroborated that most of the micropore sizes are between 0.5 and $0.75 \mathrm{~nm}$ for Coconut $\mathrm{AC}$ and varying from 0.65 to $0.75 \mathrm{~nm}$ for the Wood AC.

Table 3 shows that the concentrations of the total basic and acid sites for the ACs varied from 0.093 to $4.995 \mathrm{meq} / \mathrm{g}$ and 0.093 to $1.874 \mathrm{meq} / \mathrm{g}$, respectively. As can be seen, the total acidic and basic sites concentrations ranged widely. The Wood AC surface exhibited a more acidic character $\left(\mathrm{pH}_{\mathrm{PZC}}=3.64\right)$, considering that the concentration of acidic sites was 7.7 times larger than that of the basic ones. Otherwise, the concentration of basic sites of Coconut AC was 7-fold larger than those of acid sites $\left(\mathrm{pH}_{\mathrm{PZC}}=10.85\right)$. In general, the acid sites concentrations of the ACs decreased as follows: Wood > Coconut $>$ Norit $>$ Darco $>$ Merck, whereas the basic sites diminished in the subsequent order: Coconut > Norit $>$ Wood $>$ Merck $\approx$ Darco.

Table 3

The concentration of acidic and basic sites of the commercial ACs.

\begin{tabular}{|lll|}
\hline Activated Carbon & Total acid sites $(\mathrm{meq} / \mathrm{g})$ & Total basic sites $(\mathrm{meq} / \mathrm{g})$ \\
\hline Coconut & 0.711 & 4.995 \\
\hline Merck & 0.093 & 0.093 \\
\hline Darco & 0.141 & 0.093 \\
\hline Norit & 0.313 & 1.366 \\
\hline Wood & 1.874 & 0.243 \\
\hline
\end{tabular}

\subsection{Modeling the adsorption data of RNZ and DCF}

The adsorption isotherm of Radke-Prausnitz (R-P) interpreted the data for the adsorption equilibrium of both pharmaceuticals. This isotherm model is mathematically expressed as follows (Leyva-Ramos 2007):

$\mathrm{q}=\frac{a \mathrm{C}}{1+b \mathrm{C}^{\beta}}$

where the R-P isotherm parameters are $\beta, a(\mathrm{~L} / \mathrm{g})$ and $b\left(\mathrm{~L}^{\beta} / \mathrm{mg}^{\beta}\right)$.

The parameters for adsorption isotherm were calculated by matching the adsorption model to the data using the Rosenbrock-Newton optimization algorithm. Besides, the average percent deviation for each adsorption model, \%D, was appraised using the succeeding mathematical relationship: 


$$
\% \mathrm{D}=\left(\frac{1}{\mathrm{~N}} \sum_{\mathrm{i}=1}^{\mathrm{N}}\left|\frac{\mathrm{q}_{\mathrm{exp}}-\mathrm{q}_{\mathrm{pred}}}{\mathrm{q}_{\mathrm{exp}}}\right|\right) \times 100 \%
$$

The data were also described by the Langmuir and Freundlich isotherms (Moral-Rodríguez, 2019); however, the \%D values for the R-P isotherm model were shorter than the \%D values of the Freundlich and Langmuir adsorption models in 22 out of the 28 experimental conditions registered in Tables 4 and 5 . Therefore, the R-P model better interpreted the experimental data since it is a three-parameter isotherm, while the Langmuir and Freundlich isotherms are two-parameter adsorption models. Tables 4 and 5 list the parameters and \% D for the R-P isotherm. The R-P adsorption model adequately represented the experimental data since the \% D varied from 0.9 to $21.0 \%$.

Table 4

Parameter values of the Radke-Prausnitz adsorption isotherms for the adsorption of RNZ and DCF in aqueous solution on ACs at $\mathrm{T}=25^{\circ} \mathrm{C}$ and $\mathrm{pH}=7$.

\begin{tabular}{|c|c|c|c|c|c|}
\hline Compound & $A C$ & $\begin{array}{l}a \\
(L / g)\end{array}$ & $\begin{array}{l}\text { b } \\
\left(L^{\beta} / \mathrm{mg}^{\beta}\right)\end{array}$ & $\beta$ & $\% \mathrm{D}$ \\
\hline \multirow[t]{5}{*}{ RNZ } & Wood & 50.3 & 0.46 & 0.81 & 3.7 \\
\hline & Merck & 46.5 & 0.51 & 0.83 & 0.9 \\
\hline & Coconut & 55.6 & 0.42 & 0.80 & 8.0 \\
\hline & Norit & 165.3 & 1.26 & 0.89 & 4.4 \\
\hline & Darco & 188.1 & 3.01 & 0.82 & 4.6 \\
\hline \multirow[t]{5}{*}{ DCF } & Wood & 29.2 & 0.10 & 0.92 & 9.9 \\
\hline & Merck & 103.9 & 1.30 & 0.82 & 10.5 \\
\hline & Coconut & 709.3 & 6.70 & 0.88 & 14.1 \\
\hline & Norit & 103.9 & 1.30 & 0.82 & 4.9 \\
\hline & Darco & 5.4 & 0.05 & 0.90 & 1.8 \\
\hline
\end{tabular}


Table 5

Parameters of the Radke-Prausnitz adsorption isotherms for the adsorption of RNZ on Coconut and DCF on Wood from aqueous solution at different operating conditions and I $=0.01 \mathrm{~N}$.

\begin{tabular}{|c|c|c|c|c|c|c|c|c|c|}
\hline \multicolumn{2}{|c|}{$\begin{array}{l}\text { Operating } \\
\text { Conditions }\end{array}$} & \multicolumn{2}{|c|}{ RNZ on Coconut } & \multicolumn{4}{|c|}{ DCF on Wood } & \multirow[b]{2}{*}{$\beta$} & \multirow[b]{2}{*}{$\% \mathrm{D}$} \\
\hline $\begin{array}{l}\mathrm{T} \\
\left({ }^{\circ} \mathrm{C}\right)\end{array}$ & $\mathrm{pH}$ & $\begin{array}{l}a \\
(L / g)\end{array}$ & $\begin{array}{l}\mathrm{b} \\
(\mathrm{L} \beta / \mathrm{mg} \beta)\end{array}$ & $\beta$ & $\% \mathrm{D}$ & $\begin{array}{l}a \\
(L / g)\end{array}$ & $\begin{array}{l}\mathrm{b} \\
(\mathrm{L} \beta / \mathrm{mg} \beta)\end{array}$ & & \\
\hline 25 & 6 & & & & & 114.0 & 0.26 & 0.95 & 15.0 \\
\hline 25 & 7 & 55.6 & 0.42 & 0.80 & 8.0 & 29.2 & 0.10 & 0.92 & 9.9 \\
\hline 25 & 9 & 312.6 & 2.55 & 0.78 & 21.0 & 36.3 & 0.17 & 0.94 & 1.4 \\
\hline 25 & 11 & 27.9 & 0.20 & 0.75 & 2.5 & 118.9 & 1.15 & 0.84 & 3.1 \\
\hline 15 & 7 & 84.2 & 0.63 & 0.84 & 9.0 & 22.7 & 0.23 & 0.78 & 18.6 \\
\hline 25 & 7 & 55.6 & 0.42 & 0.80 & 8.0 & 29.2 & 0.10 & 0.92 & 9.9 \\
\hline 35 & 7 & 167.2 & 1.34 & 0.80 & 1.0 & 23.7 & 0.06 & 0.97 & 2.0 \\
\hline
\end{tabular}

At $\mathrm{T}=25{ }^{\circ} \mathrm{C}$ and $\mathrm{pH}=7$, the isotherms of RNZ and DCF adsorbed on ACs are shown in Fig. 2a and $2 \mathrm{~b}$. As depicted in Fig. 2a, the capacities of ACs for adsorbing RNZ in water solution diminished as follows: Coconut $>$ Wood $>$ Norit $>$ Merck $>$ Darco. At the RNZ equilibrium concentration of $500 \mathrm{mg} / \mathrm{L}$, the uptake of RNZ adsorbed $\left(Q_{500}\right)$ upon the Coconut, Wood, Norit, Merck and Darco is 434, 350, 283, 261 and 188 $\mathrm{mg} / \mathrm{g}$, respectively. It can be noted that Coconut and Darco presented the largest and lowest adsorption capacity towards RNZ. In Fig. $2 \mathrm{~b}$, it is observed that Wood had the highest adsorption capacity towards DCF. The $Q_{500}$ for DCF $\left(Q_{500}\right)$ on the Wood, Merck, Coconut, Norit and Darco is 396, 248, 222, 182 and 166 $\mathrm{mg} / \mathrm{g}$, correspondingly, so that the AC capacities for adsorbing DCF decreased in the subsequent series: Wood $>$ Merck $>$ Coconut $>$ Norit $>$ Darco .

In this work, the maximum uptake of RNZ adsorbed on Coconut AC was $444 \mathrm{mg} / \mathrm{g}$ at pH of 7 and T of $25^{\circ} \mathrm{C}$ and was slightly larger than those presented in previous studies (Méndez-Díaz et al. 2010; MoralRodríguez et al. 2016). The maximum adsorption capacities of three commercial carbons towards RNZ ranged from 376 to $394 \mathrm{mg} / \mathrm{g}$ (Méndez-Díaz et al. 2010; Moral-Rodríguez et al. 2016). While the Wood AC presented the maximum uptake of DCF adsorbed of $441 \mathrm{mg} / \mathrm{g}$, which is within the range (47.12-1033 $\mathrm{mg} / \mathrm{g}$ ) found for the adsorption capacities of pristine and modified ACs (Moral-Rodriguez et al. 2019; Viotti et al. 2019).

Figure 3 depicts the molar uptake of DCF and RNZ adsorbed for the concentration at equilibrium of 500 $\mathrm{mg} / \mathrm{g}, \mathrm{Q}_{500}(\mathrm{mmol} / \mathrm{g})$, graphed vs. the BET surface area of the AC. It can be noticed that the capacity of 
ACs for DCF incremented approximately linearly by augmenting $S_{B E T}$. In the case of RNZ, the capacity of ACs for adsorbing RNZ increased somehow linearly with surface area, except for the Coconut AC. The finding that the surface area affected the adsorption capacity corroborated that the $\pi-\pi$ dispersive interactions were the predominant adsorption mechanism. These interactions are related to the $\pi$ electrons of the aromatic ring of RNZ or DCF and the $\pi$ electrons existing in the AC graphene planes. The Coconut AC had the greatest adsorption capacity towards RNZ, but the Coconut AC did not have the highest $S_{B E T}$ and was the $A C$ having the largest concentration of basic sites. This result demonstrated that the surface chemistry of ACs could also affect their adsorption capacity.

The molar $\mathrm{Q}_{500}$ of RNZ was always higher than that of DCF independently of the AC. This result can be ascribed to the molecular dimensions of RNZ (Table 1), which are shorter than those of DCF so that the RNZ molecules can access more micropores than the DCF molecules, and more adsorption sites are available for adsorbing RNZ.

The molar $\mathrm{Q}_{500}$ for RNZ and DFC vs. the concentration of acidic sites per unit surface area of AC (acidic sites/ $\left.\mathrm{S}_{\mathrm{BET}}\right)$ are plotted in Fig. 4. Overall, the acidic sites concentration promoted the adsorption capacity of ACs. Except for Merck AC, the capacities of the ACs for adsorbing DCF were raised linearly by increasing the concentration of acidic sites. Again, the Coconut AC exhibited the highest $Q_{500}$ for RNZ, but this carbon did not have the largest concentration of acidic sites. The acidic site concentration favored the $A C$ adsorption capacity because some of the acidic sites can activate the $\pi-\pi$ dispersion interactions (Carrales-Alvarado et al. 2014). The results indicated that the textural and chemical characteristics of ACs significantly influenced the ACs adsorption capacities towards RNZ and DCF from water solutions.

\subsection{Influence of pH on the capacity of Coconut AC for adsorbing RNZ}

The dependence of the Coconut AC capacity for RNZ on the pH is exhibited in Fig. 5, and the adsorption capacity rises marginally by augmenting the $\mathrm{pH}$ from 3 to 7 ; however, at $\mathrm{pH}=11$, the adsorption of RNZ on Coconut AC was significantly enhanced when the concentrations of RNZ at equilibrium were higher than $200 \mathrm{mg} / \mathrm{L}$. For the RNZ concentration of $300 \mathrm{mg} / \mathrm{L}$, the RNZ uptakes at pH 3, 7, and 11 were 364, 389 , and $548 \mathrm{mg} / \mathrm{g}$, respectively. Therefore, the mass of RNZ adsorbed at pH 11 was 1.5 and 1.4-fold higher than those at $\mathrm{pH} 3$ and 7 , respectively.

The above results can be rationalized according to the speciation diagram of RNZ (Fig. 1), which indicates that in the $\mathrm{pH}$ range of $3-9$, the RNZ molecule exists as the undissociated species, and the surface of the Coconut $A C$ is positively charged $\left(\mathrm{pH}_{\mathrm{PZC}}=10.85\right)$. Hence, in this $\mathrm{pH}$ range, the electrostatic interactions did not influence the adsorption of RNZ, confirming that the RNZ is adsorbed on Coconut AC by $\pi-\pi$ interactions mainly. Although the surface of the Coconut AC is now slightly negatively charged at $\mathrm{pH}=11$, and the RNZ is still present as the neutral species, substantiating that the RNZ adsorption was not changed by electrostatic interactions. However, at $\mathrm{pH}=11$, the adsorption capacity increased for concentrations higher than $100 \mathrm{mg} / \mathrm{L}$. The increase was due to the reduction of the RNZ solubility since 
the concentration of $\mathrm{Na}^{+}$ions is augmented by incrementing the solution $\mathrm{pH}$. Consequently, the hydrophobic interactions between the surface of the Coconut AC and the RNZ were favored. Thus, the adsorption of $\mathrm{RNZ}$ en Coconut $\mathrm{AC}$ at $\mathrm{pH}=11$ is related to the $\pi-\pi$ dispersive interactions and hydrophobic effect.

\subsection{Influence of pH on the capacity of Wood AC for adsorbing DCF}

Figure 6 illustrates the $\mathrm{pH}$ influence on the capacity of Wood AC for adsorbing DCF. The adsorption capacity diminished considerably and moderately by incrementing the $\mathrm{pH}$ from 6 to 9 and 9 to 11, correspondingly. None adsorption runs were performed at $\mathrm{pH}<6$ because the DCF solubility in water is low (Llinàs et al. 2007). For a DCF equilibrium concentration of $300 \mathrm{mg} / \mathrm{L}$, the uptake of DCF adsorbed was 568, 353, 278 and $244 \mathrm{mg} / \mathrm{g}$ for the $\mathrm{pH}$ values of $6,7,9$ and 11, correspondingly. The capacity of Wood $\mathrm{AC}$ at $\mathrm{pH}=6$ was 1.6, 2.0 and 2.3 times higher than those at $\mathrm{pH}$ of 7, 9 and 11 .

The above behavior can be ascribed to the fact that the DCF molecules in water are the anionic species $\left(\mathrm{DCF}^{-}\right)$in the $\mathrm{pH}$ span from 6 to 11, while the surface of Wood $\mathrm{AC}$ is negatively charged $\left(\mathrm{pH}_{\mathrm{PZC}}=3.64\right)$. Thus, the lessening of the adsorption capacity was associated with the increment of the electrostatic repellence existing between the surface of the Wood $A C$ and $\mathrm{DCF}^{-}$because the negative charge of $\mathrm{AC}$ surface augments by raising the $\mathrm{pH}$.

The influence of the electrostatic interactions in the DCF adsorption mechanism on Wood AC was further analyzed by carrying out adsorption runs at the solution ionic strengths of $0.01,0.1$ and 1.0 N (MoralRodriguez, 2019). The results (not shown in this work) demonstrated that the capacity of Wood AC for adsorbing DCF increased while raising the ionic strength. The ionic strength was varied by changing the $\mathrm{NaCl}$ concentration in the solution, so the $\mathrm{Na}^{+}$ions adsorb on the AC negative surface, balancing the negative charge of the AC and decreasing the repulsion between $\mathrm{DCF}^{-}$and the Wood AC surface, enhancing the adsorption of DCF. This effect is known as the screening effect (Moreno-Castilla 2004).

\subsection{Effect of temperature on the capacity of Coconut and Wood ACs for adsorbing RNZ and DCF}

The influence of temperature on the uptake of RNZ and DCF adsorbed on Coconut and Wood $\mathrm{ACs}$ at $\mathrm{pH}=$ 7 is depicted in Fig. 7. For an RNZ equilibrium concentration of 400 mg/L (See Fig. 7a), the uptake of RNZ adsorbed on Coconut AC was promoted and non-influenced by incrementing the temperature from 15 to $25^{\circ} \mathrm{C}$ and 25 to $35^{\circ} \mathrm{C}$, respectively. A comparable tendency was also noted for the adsorption of RNZ on an AC commercially known as Filtrasorb 400 when the temperature varied from 10 to $40^{\circ} \mathrm{C}$ (MoralRodríguez et al. 2016). The mass of RNZ adsorbed at 35, 25 and $15^{\circ} \mathrm{C}$ was 408, 403 and $352 \mathrm{mg} / \mathrm{g}$, correspondingly indicating that the capacity of Coconut AC increased $14.5 \%$ when the temperature rose from 15 to $25^{\circ} \mathrm{C}$. Likewise, Fig. 7b shows that the adsorption of DCF was significantly influenced by 
increasing the temperature from 15 to 25 and slightly augmented from 25 to $35^{\circ} \mathrm{C}$. For a DCF concentration of $400 \mathrm{mg} / \mathrm{g}$, the uptakes of DCF adsorbed were 363,413 and $427 \mathrm{mg} / \mathrm{g}$ at 15, 25 and $35^{\circ} \mathrm{C}$. These outcomes verified that the adsorption capacity of Wood AC towards DCF was raised $14 \%$ and $3.4 \%$ while incrementing the temperature from 15 to $25^{\circ} \mathrm{C}$ and 25 to $35^{\circ} \mathrm{C}$.

The isosteric adsorption heat, $\left(\Delta \mathrm{H}_{\mathrm{ads}}\right)_{\mathrm{q}}$, for RNZ and $\mathrm{DCF}$, was estimated using the experimental data at 15 and $25^{\circ} \mathrm{C}$ since the adsorption capacity varied in this temperature range. The $\left(\Delta \mathrm{H}_{\text {ads }}\right)_{\mathrm{q}}$ was estimated employing the following equation (Leyva-Ramos 1989):

$$
\left(\Delta \mathrm{H}_{\mathrm{ads}}\right)_{\mathrm{q}}=\frac{\mathrm{R} \operatorname{Ln} \frac{\mathrm{C}_{2}}{\mathrm{C}_{1}}}{\frac{1}{\mathrm{~T}_{2}}-\frac{1}{\mathrm{~T}_{1}}}
$$

where $\left(\Delta \mathrm{H}_{\mathrm{ads}}\right)_{\mathrm{q}}$ is the isosteric adsorption enthalpy, $\mathrm{J} / \mathrm{mol}$; $\mathrm{R}$ is the gas law constant, $8.314 \mathrm{~J} / \mathrm{K} \mathrm{mol} ; \mathrm{C}_{2}$ and $\mathrm{C}_{1}$ are the equilibrium concentrations of the pharmaceutical at temperatures $T_{2}$ and $T_{1}$, correspondingly, and at the same mass of the pharmaceutical adsorbed at equilibrium (q), mg/L; $T_{2}$ and $\mathrm{T}_{1}$ are the temperatures at the conditions 2 and 1, respectively, $\mathrm{K}$.

The $\Delta \mathrm{H}_{\text {ads }}$ was estimated to be 56.5 and $56.3 \mathrm{~kJ} / \mathrm{mol}$ for the adsorption of RNZ on Coconut AC at $\mathrm{q}=358$ $\mathrm{mg} / \mathrm{g}$, and DCF on Wood AC at $\mathrm{q}=372 \mathrm{mg} / \mathrm{g}$, correspondingly. Thus, the adsorption of both pharmaceuticals was endothermic. It is worthwhile to mention that the $\Delta \mathrm{H}_{\mathrm{ads}}$ decreased as the $\mathrm{q}$ was reduced because the experimental adsorption equilibrium data were overlapped for q less than $270 \mathrm{mg} / \mathrm{g}$.

\section{Conclusions}

Coconut, Wood, Merck, Norit and Darco ACs presented different textural and physicochemical properties. The $S_{B E T}$ varied from 510 to $1357 \mathrm{~m}^{2} / \mathrm{g}$, and the cumulative volume of micropores ranged from 34 to 86 $\%$. The Wood AC had an acid character, whereas the Coconut AC showed a basic character. The Coconut AC exhibited the highest adsorption capacity towards RNZ (444 mg/g), while the Wood AC showed the maximum mass of DFC adsorbed $(405 \mathrm{mg} / \mathrm{g}$ ) from water solutions.

The surface area, as well as the acid sites concentration, significantly influenced the adsorption capacity of all ACs, corroborating that the predominant adsorption mechanism was the $\pi-\pi$ stacking interactions. Besides, in the $\mathrm{pH}$ span of 3-7, the electrostatic interactions did not affect the adsorption of RNZ on Coconut $\mathrm{AC}$; however, the hydrophobic interactions favored the adsorption of RNZ at pH $=11$. In contrast, the capacity of Wood AC for DCF was reduced by the electrostatic repellence occurring between the negatively charged surface of the AC and the anionic DCF.

The uptake of RNZ adsorbed on Coconut AC and DCF adsorbed on Wood AC was lessened by diminishing the temperature from 25 to $15^{\circ} \mathrm{C}$; hence, the adsorption of RNZ and DCF was endothermic in 
this temperature range. However, it remained nearly constant, incrementing the temperature from 25 and $35^{\circ} \mathrm{C}$.

The adsorption on ACs is a feasible process for efficiently removing RNZ and DCF from aqueous solutions, but the textural and chemical properties must be considered in selecting the proper commercial AC.

\section{Declarations}

\section{ACKNOWLEDGMENT}

E. Mendoza-Mendoza thanks for the financial support to CONACyT through the Catedras program, project No. 864. This study was financially supported by Fondo de Apoyo a la Investigación (FAl)-Universidad Autonoma de San Luis Potosi (UASLP), through grant No.: C20-FAl-10-27.27.

Authors' contributions AIMR carried out data curation, methodology, investigation, writing-original draft preparation and visualization. RLR performed funding acquisition, investigation, project administration, supervision, methodology, writing, reviewing and editing. EMM accomplished conceptualization, supervision, methodology, writing, reviewing and Editing. PEDF engaged in methodology, writing-original draft preparation and visualization. DHCA participated in data curation, methodology and writing-original draft preparation. MFAF carried out methodology, investigation and characterization of activated carbons. CFG performed methodology, investigation and characterization of activated carbons.

Availability of data and materials Datasets used during the current study and supplementary data are available from the corresponding author on reasonable request.

\section{Compliance with ethical standards}

Ethics approval and consent to participate Not applicable.

Consent for publication No applicable.

Competing interests The authors declare that they have no competing interests.

\section{References}

1. Babić BM, Milonjić SK, Polovina MJ, Kaludierović BV (1999) Point of zero charge and intrinsic equilibrium constants of activated carbon cloth. Carbon. https://doi.org/10.1016/S00086223(98)00216-4

2. Boehm HP (1966) Chemical identification of surface groups. Adv Catal. https://doi.org/10.1016/S0360-0564(08)60354-5

3. Brunauer S, Emmett PH, Teller E (1938) Adsorption of gases in multimolecular layers. J Am Chem Soc. https://doi.org/10.1021/ja01269a023 
4. Carrales-Alvarado DH, Ocampo-Pérez R, Leyva-Ramos R, Rivera-Utrilla J (2014) Removal of the antibiotic metronidazole by adsorption on various carbon materials from aqueous phase. $\mathrm{J}$ Colloid Interface Sci. https://doi.org/10.1016/j.jcis.2014.08.023

5. Chianese S, lovino P, Canzano $S$ et al (2016) Ibuprofen degradation in aqueous solution by using UV light. Desalin Water Treat. https://doi.org/10.1080/19443994.2016.1153908

6. Díaz-Cruz MS, García-Galán MJ, Barceló D (2008) Highly sensitive simultaneous determination of sulfonamide antibiotics and one metabolite in environmental waters by liquid chromatographyquadrupole linear ion trap-mass spectrometry. J Chromatogr A. https://doi.org/10.1016/j.chroma.2008.03.029

7. Dos Reis GS, Bin Mahbub MK, Wilhelm M et al (2016) Activated carbon from sewage sludge for removal of sodium diclofenac and nimesulide from aqueous solutions. Korean $\mathrm{J}$ Chem Eng. https://doi.org/10.1007/s11814-016-0194-3

8. Du J, Mei CF, Ying GG, Xu MY (2016) Toxicity Thresholds for diclofenac, acetaminophen and ibuprofen in the water flea daphnia magna. Bull Environ Contam Toxicol. https://doi.org/10.1007/s00128-016-1806-7

9. Gómez MJ, Martínez Bueno MJ, Lacorte S et al (2007) Pilot survey monitoring pharmaceuticals and related compounds in a sewage treatment plant located on the Mediterranean coast. Chemosphere. https://doi.org/10.1016/j.chemosphere.2006.07.051

10. Halling-Sørensen B, Nors Nielsen S, Lanzky PF et al (1998) Occurrence, fate and effects of pharmaceutical substances in the environment- A review. Chemosphere. https://doi.org/10.1016/S0045-6535(97)00354-8

11. Jeon J, Hollender J (2019) In vitro biotransformation of pharmaceuticals and pesticides by trout liver S9 in the presence and absence of carbamazepine. Ecotoxicol Environ Saf. https://doi.org/10.1016/j.ecoenv.2019.109513

12. Kümmerer K (2009) Antibiotics in the aquatic environment - A review - Part I. Chemosphere. https://doi.org/10.1016/j.chemosphere.2008.11.086

13. Leyva-Ramos $\mathrm{R}$ (1989) Effect of temperature and $\mathrm{pH}$ on the adsorption of an anionic detergent on activated carbon. J Chem Technol Biotechnol. https://doi.org/10.1002/jctb.280450308

14. Leyva-Ramos R (2007) Importancia y aplicaciones de la adsorción en fase líquida. In: MorenoPiraján JM(ed) Sólidos porosos, Preparación, Caracterización y Aplicaciones. Ediciones Uniandes, Bogotá, Colombia, pp 155-211

15. Lin AYC, Yu TH, Lin CF (2008) Pharmaceutical contamination in residential, industrial, and agricultural waste streams: Risk to aqueous environments in Taiwan. Chemosphere. https://doi.org/10.1016/j.chemosphere.2008.08.027

16. Lin AYC, Tsai YT (2009) Occurrence of pharmaceuticals in Taiwan's surface waters: Impact of waste streams from hospitals and pharmaceutical production facilities. Sci Total Environ. https://doi.org/10.1016/j.scitotenv.2009.03.009 
17. Llinàs A, Burley JC, Box KJ et al (2007) Diclofenac solubility: Independent determination of the intrinsic solubility of three crystal forms. J Med Chem. https://doi.org/10.1021/jm0612970

18. Malhotra M, Suresh S, Garg A (2018) Tea waste derived activated carbon for the adsorption of sodium diclofenac from wastewater: adsorbent characteristics, adsorption isotherms, kinetics, and thermodynamics. Environ Sci Pollut Res. https://doi.org/10.1007/s11356-018-3148-y

19. Martínez-Costa JI, Maldonado Rubio MI, Leyva-Ramos R (2020) Degradation of emerging contaminants diclofenac, sulfamethoxazole, trimethoprim and carbamazepine by bentonite and vermiculite at a pilot solar compound parabolic collector. Catal Today. https://doi.org/10.1016/j.cattod.2018.07.021

20. Méndez-Díaz JD, Prados-Joya G, Rivera-Utrilla J et al (2010) Kinetic study of the adsorption of nitroimidazole antibiotics on activated carbons in aqueous phase. J Colloid Interface Sci. https://doi.org/10.1016/j.jcis.2010.01.089

21. Moral-Rodríguez Al, Leyva-Ramos R, Ocampo-Pérez R et al (2016) Removal of ronidazole and sulfamethoxazole from water solutions by adsorption on granular activated carbon: equilibrium and intraparticle diffusion mechanisms. Adsorption. https://doi.org/10.1007/s10450-016-9758-0

22. Moral-Rodríguez Al, Leyva-Ramos R, Ania CO et al (2019) Tailoring the textural properties of an activated carbon for enhancing its adsorption capacity towards diclofenac from aqueous solution. Environ Sci Pollut Res. https://doi.org/10.1007/s11356-018-3991-x

23. Moreno-Castilla C (2004) Adsorption of organic molecules from aqueous solutions on carbon materials. Carbon. https://doi.org/10.1016/j.carbon.2003.09.022

24. Richard HD, Mycek MJ, Harvey RA, Champe PC (2007) Lippincott's Illustrated Reviews: Pharmacology. Lippincott Williams \& Wilkins

25. Rouquerol F, Rouquerol J, Sing KSW et al (2014) Adsorption by powders and porous solids: Principles, methodology and applications. Academic Press, France

26. Santos LHMLM, Gros M, Rodriguez-Mozaz S et al (2013) Contribution of hospital effluents to the load of pharmaceuticals in urban wastewaters: Identification of ecologically relevant pharmaceuticals. Sci Total Environ. https://doi.org/10.1016/j.scitotenv.2013.04.077

27. Spongberg AL, Witter JD (2008) Pharmaceutical compounds in the wastewater process stream in Northwest Ohio. Sci Total Environ. https://doi.org/10.1016/j.scitotenv.2008.02.042

28. Ternes TA, Hirsch R (2000) Occurrence and behavior of X-ray contrast media in sewage facilities and the aquatic environment. Environ Sci Technol. https://doi.org/10.1021/es991118m

29. Viotti PV, Moreira WM, dos Santos OAA et al (2019) Diclofenac removal from water by adsorption on Moringa oleifera pods and activated carbon: Mechanism, kinetic and equilibrium study. J Clean Prod. https://doi.org/10.1016/j.jclepro.2019.02.129

30. Wang J, Wang S (2016) Removal of pharmaceuticals and personal care products (PPCPs) from wastewater: A review. J Environ Manage 182:620-640. https://doi.org/10.1016/j.jenvman.2016.07.049 
31. Watkinson AJ, Murby EJ, Kolpin DW, Costanzo SD (2009) The occurrence of antibiotics in an urban watershed: From wastewater to drinking water. Sci Total Environ.

https://doi.org/10.1016/j.scitotenv.2008.11.059

\section{Figures}

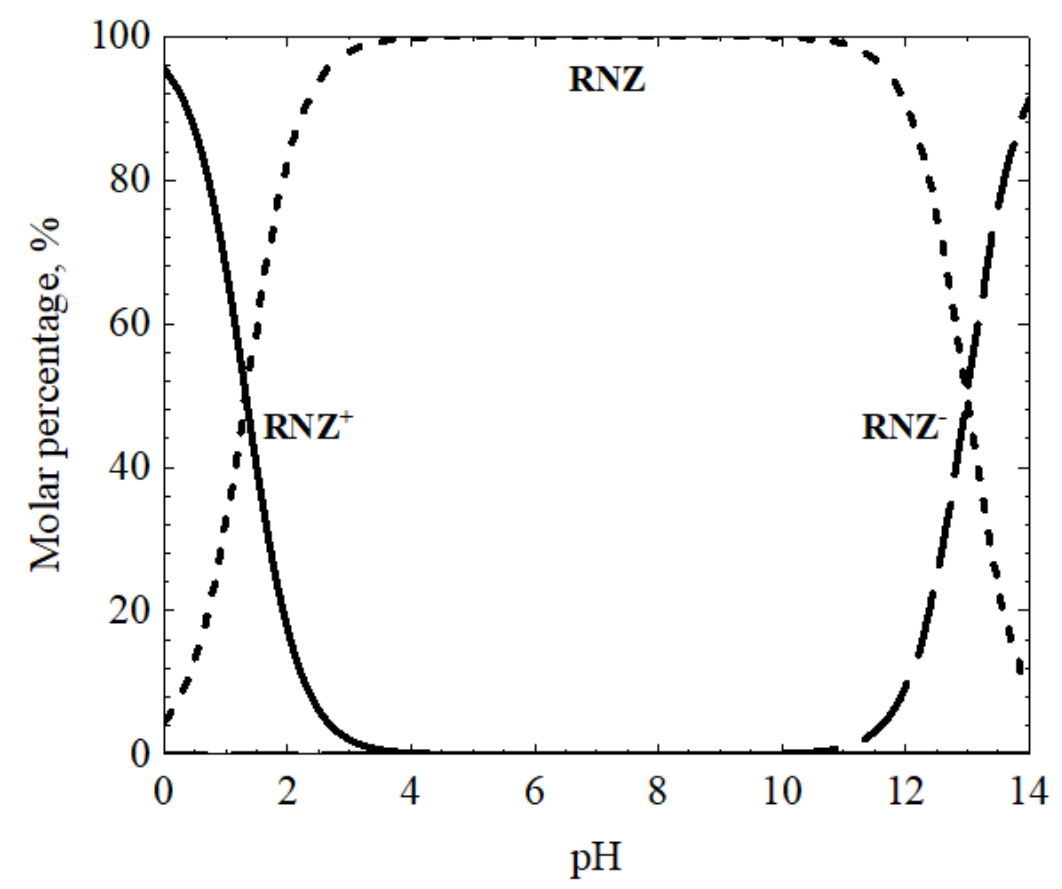

(a)

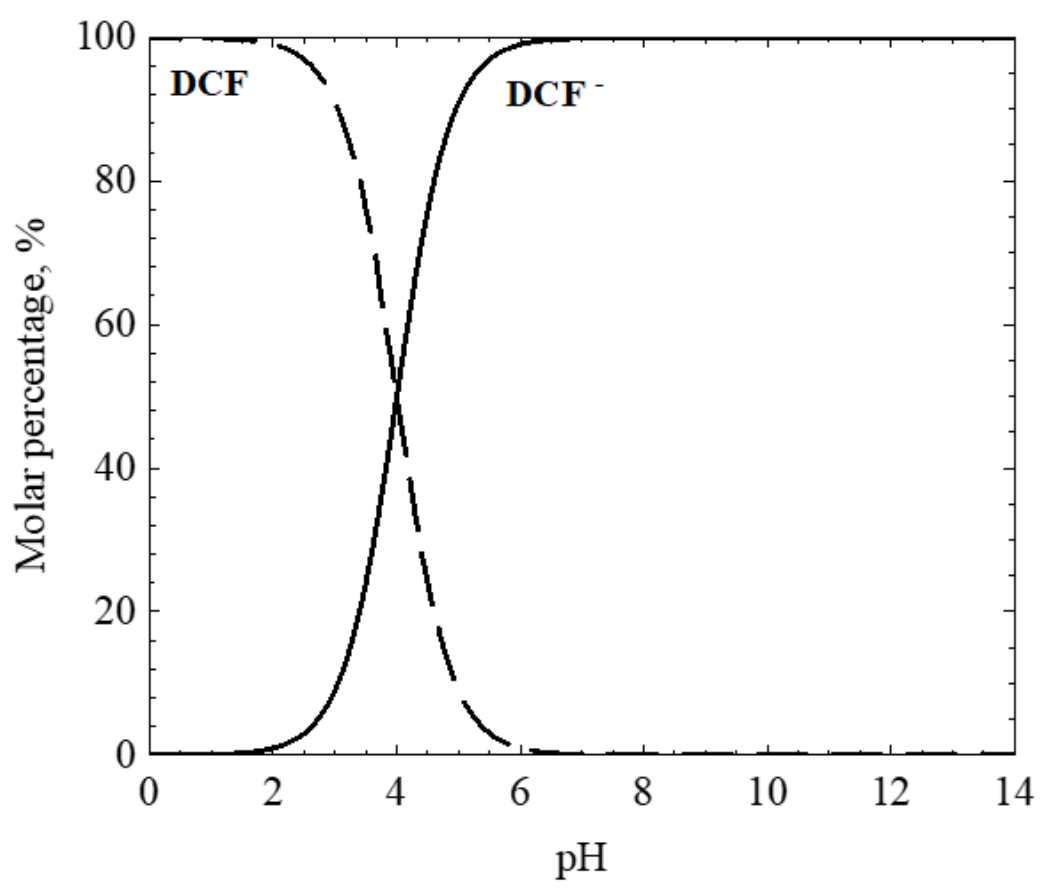

(b)

Figure 1 
Speciation diagrams of 1a) RNZ and 1b) DCF in aqueous solution as a function of the solution $\mathrm{pH}$.

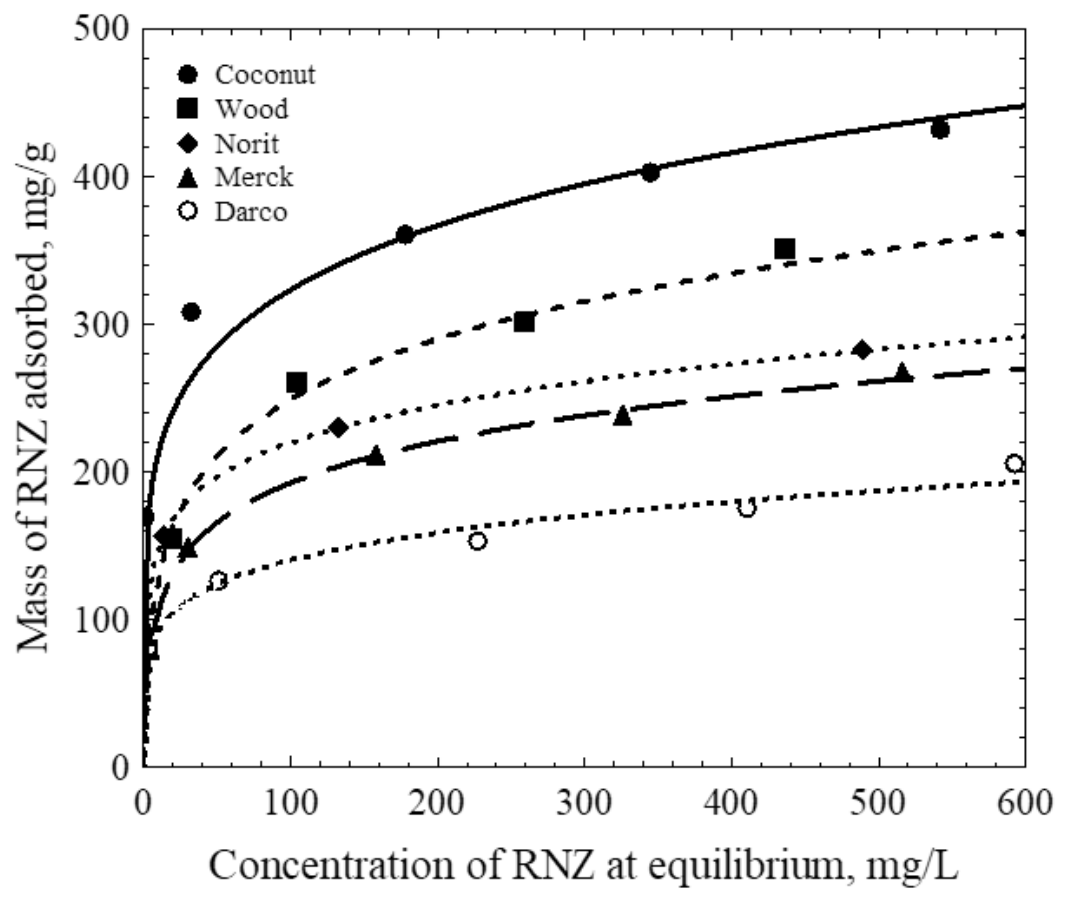

(a)

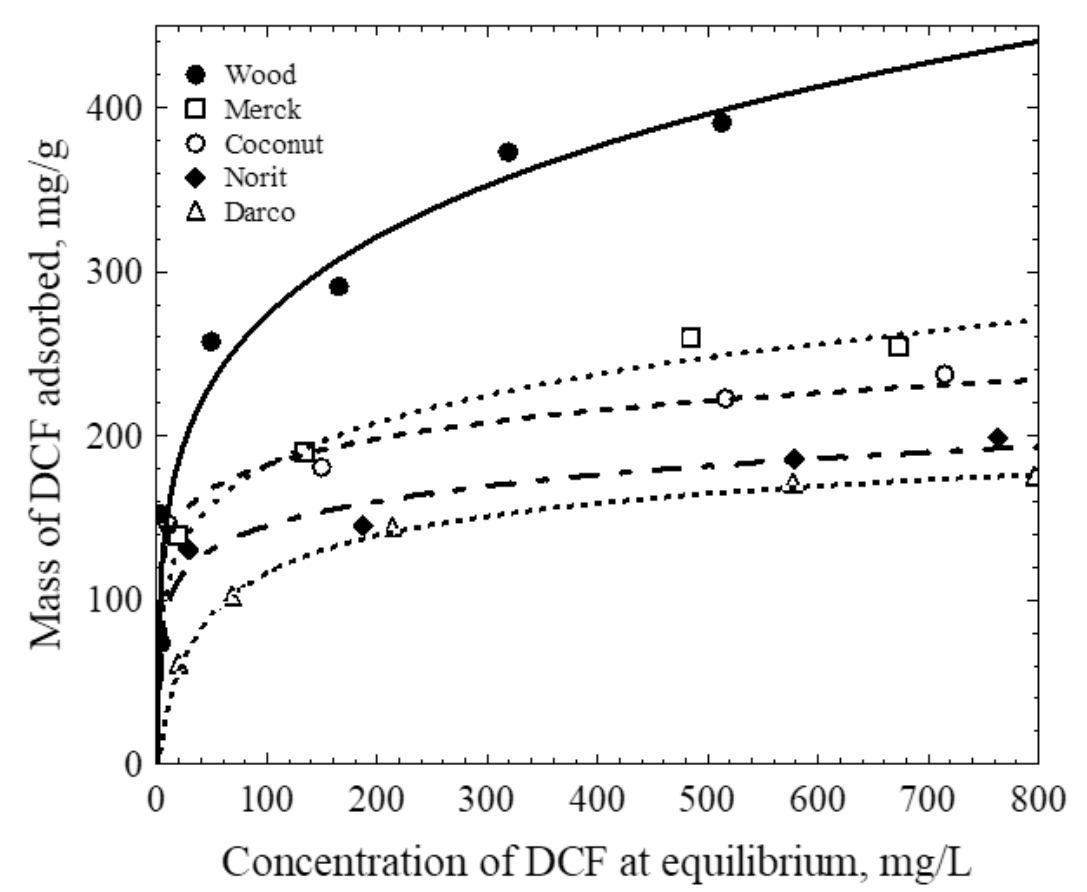

(b)

Figure 2

Adsorption isotherms of a) RNZ and b) $\mathrm{DCF}$ at $\mathrm{pH}=7$ on ACs at $\mathrm{T}=25^{\circ} \mathrm{C}$ and $\mathrm{I}=0.01 \mathrm{~N}$. The lines represent the predictions of the Radke-Prausnitz isotherm. 


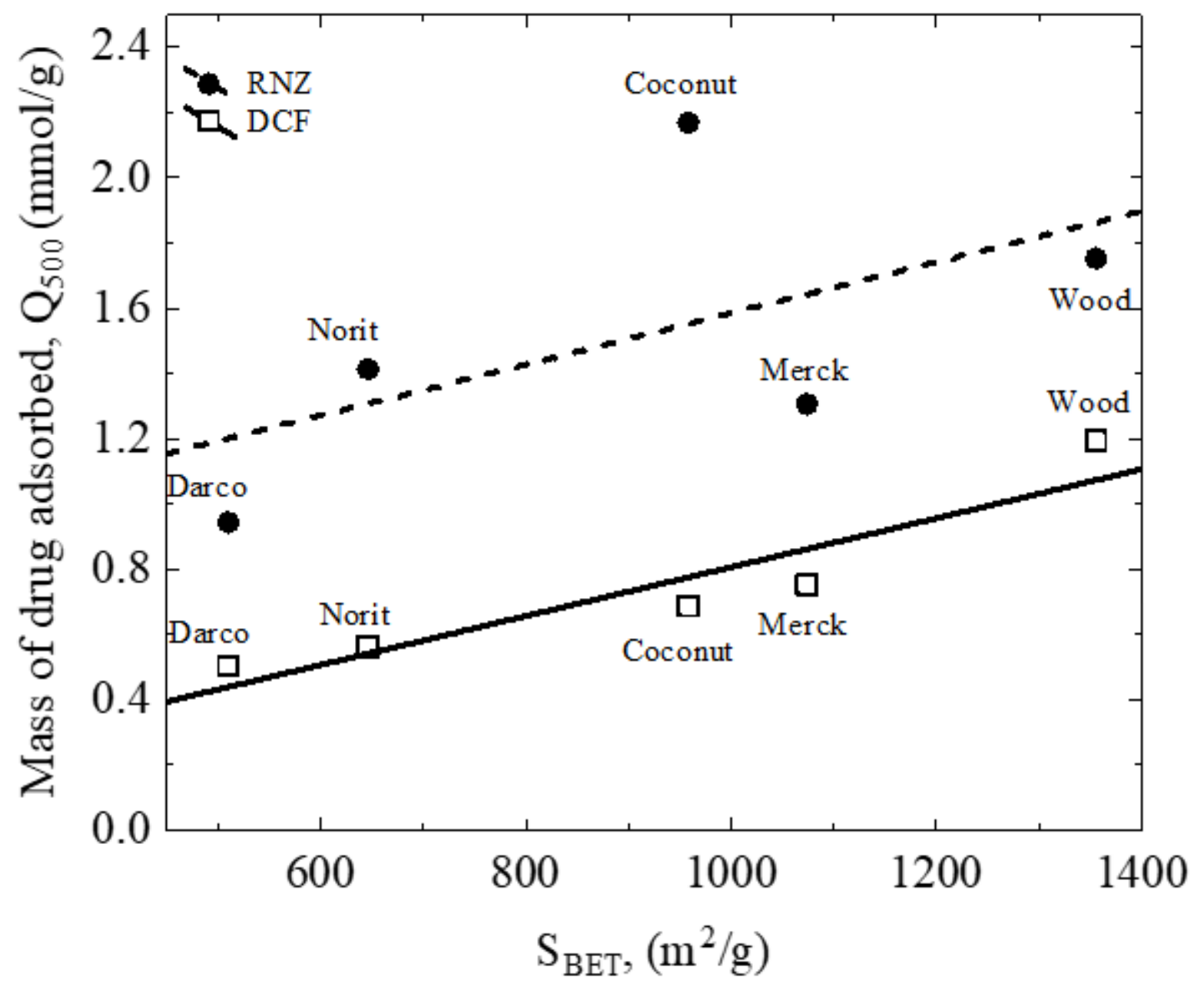

Figure 3

Effect of surface area on the adsorption capacity of the ACs. 


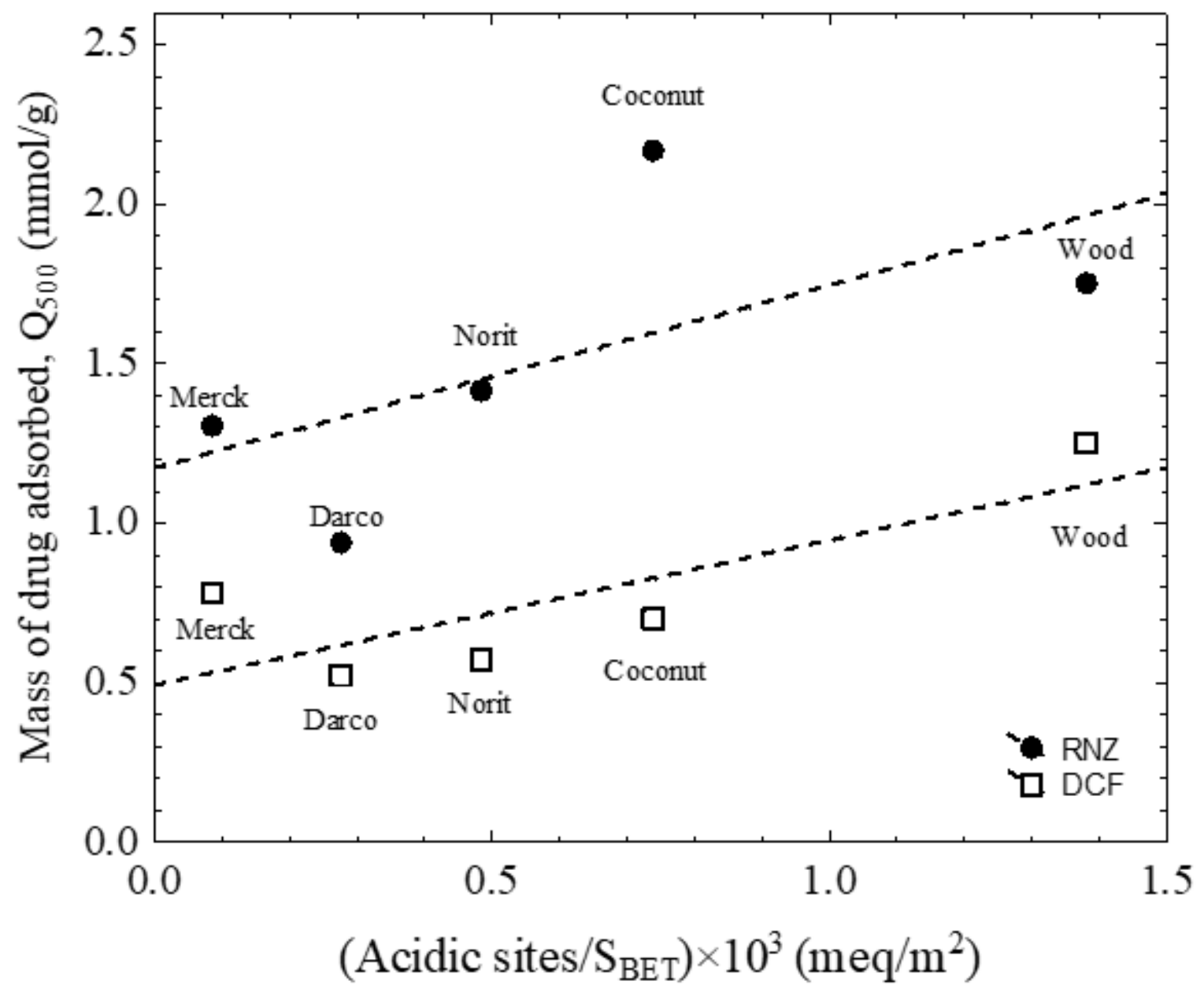

Figure 4

Dependence of the adsorption capacity of ACs on the concentrations of the acidic sites per unit of surface area. 


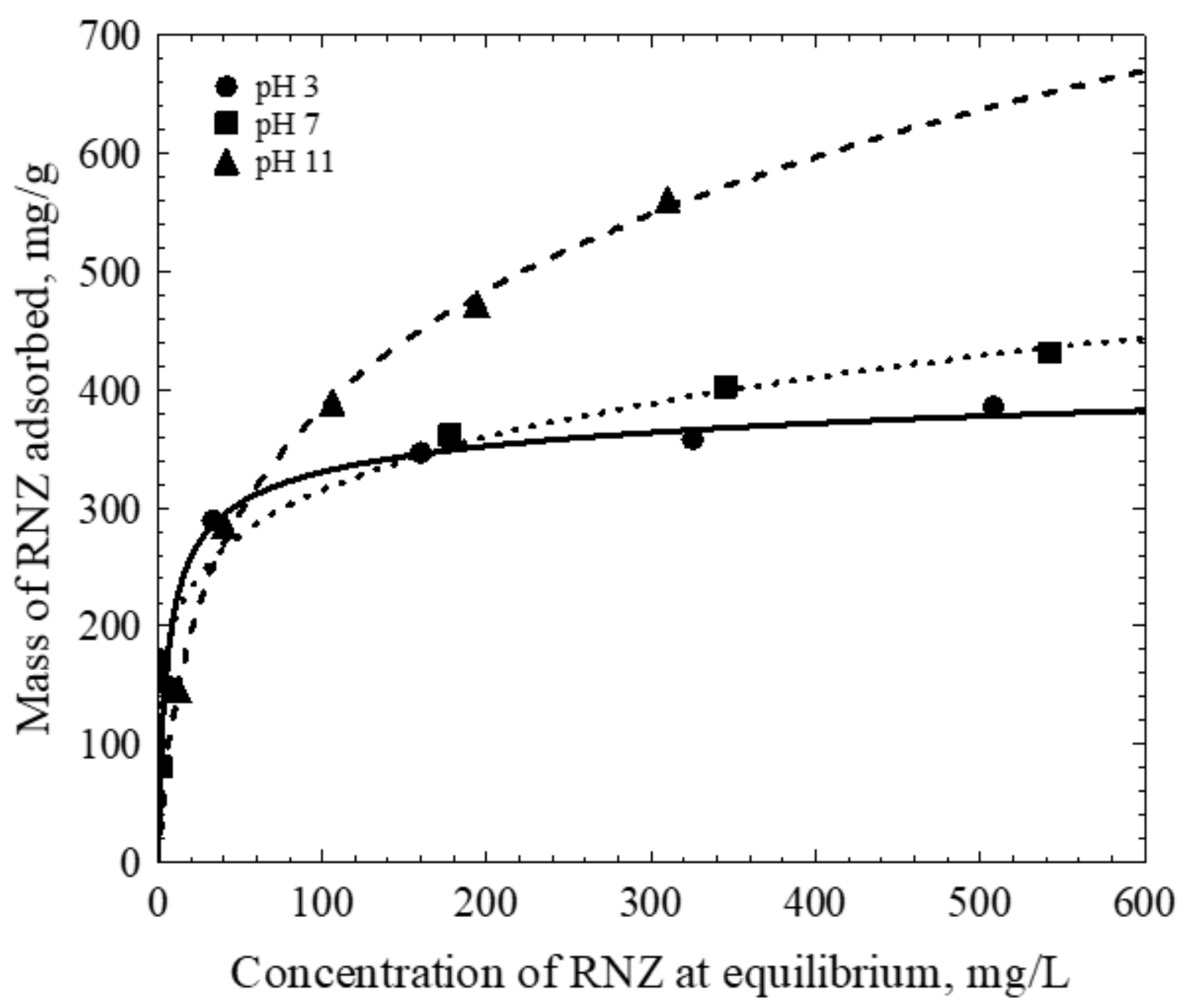

Figure 5

Effect of solution $\mathrm{pH}$ on the adsorption isotherm of RNZ on Coconut $\mathrm{AC}$ at $\mathrm{T}=25^{\circ} \mathrm{C}$ and $\mathrm{I}=0.01 \mathrm{~N}$. The lines were predicted with the Radke-Prausnitz model. 


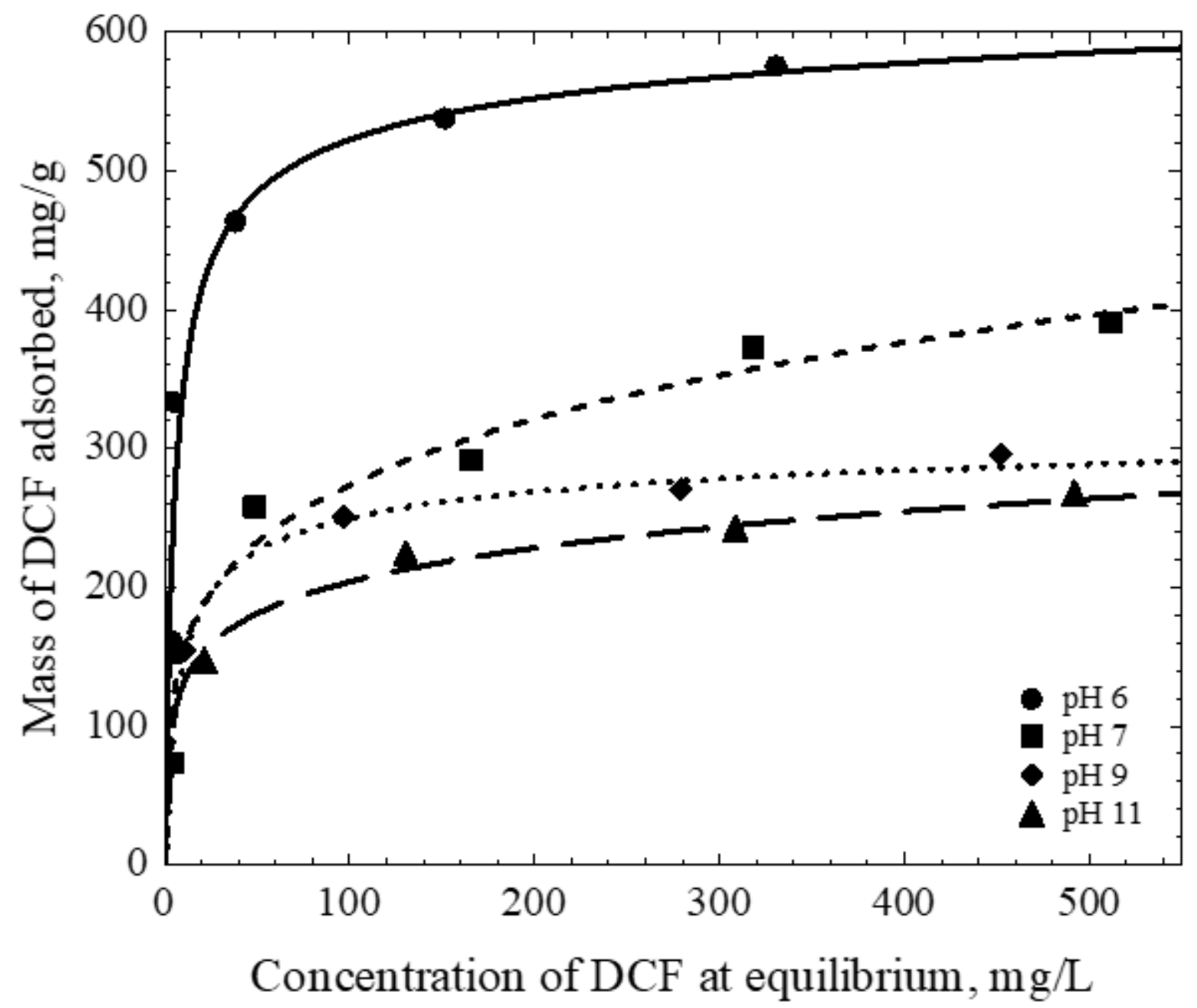

Figure 6

Effect of solution pH on the adsorption isotherm of DCF on Wood AC at T $=25^{\circ} \mathrm{C}$ and I $=0.01 \mathrm{~N}$. The lines show the prediction of the Radke-Prausnitz isotherm. 


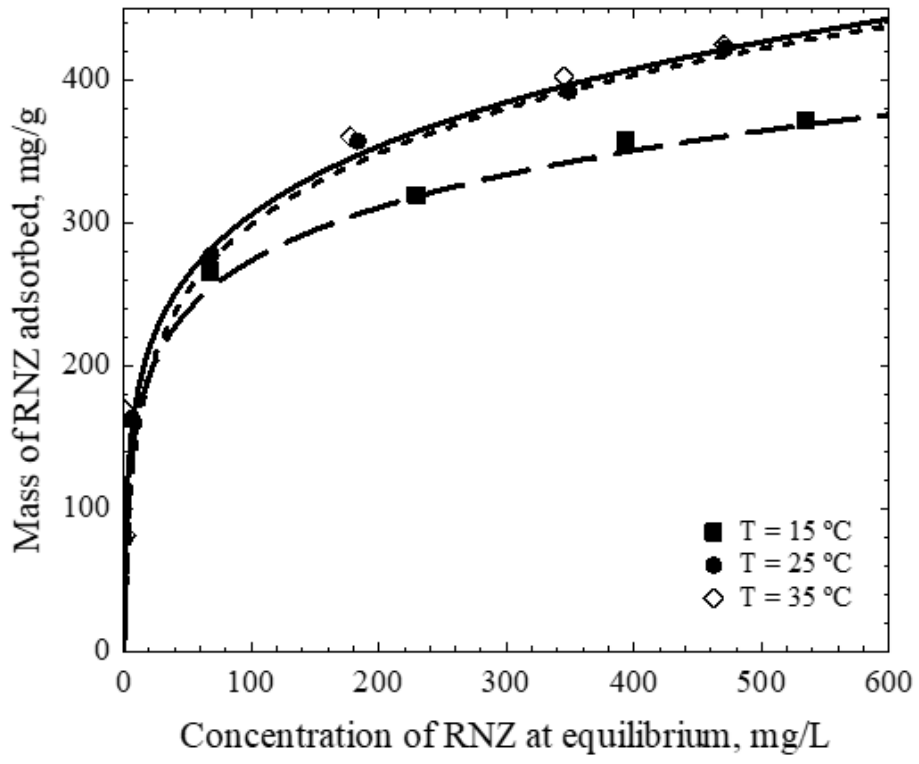

(a)

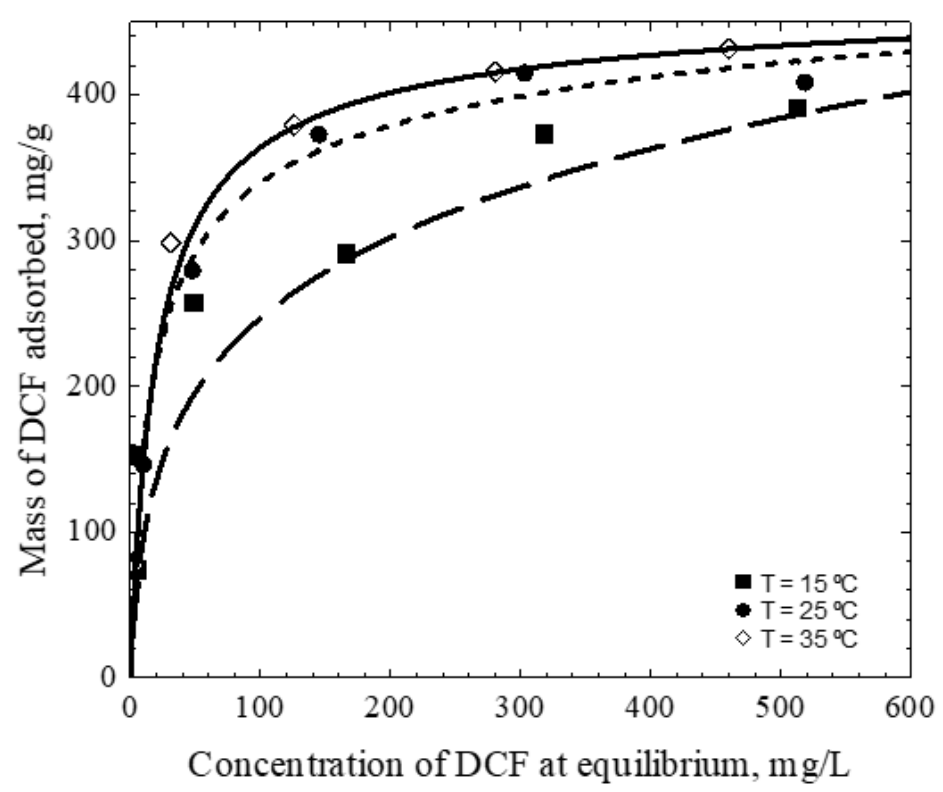

(b)

Figure 7

Effect of temperature on the adsorption isotherms of a) RNZ on Coconut AC and b) DCF on Wood AC at $\mathrm{pH}=7$ and $\mathrm{I}=0.01 \mathrm{~N}$. The lines represent the isotherm of the Radke-Prausnitz model.

\section{Supplementary Files}

This is a list of supplementary files associated with this preprint. Click to download.

- SupplementaryMaterialESPR.docx 